\title{
A MÚSICA COMO FERRAMENTA TERAPÊUTICA NO CUIDADO A CRIANÇAS E ADOLESCENTES INTERNADOS COM CÂNCER
}

\author{
Menezes, Evelyn Torres de; Muniz, Camila Silva \\ Centro Unaversitario Adventista de Sao Paulo - evelynstorres@hotmail.com
}

Introdução: o câncer infanto-juvenil é um problema de saúde pública, tornando-se fundamental direcionar os esforços e recursos para orientar estratégias do cuidado desses pacientes nos diferentes níveis de atuação. a hospitalização de crianças com câncer é uma vivência traumática, onde parecem esquecer que a criança é criança, que necessita de espaço físico, atividades e atenções apropriadas à sua faixa etária. a música pode reduzir a tensão e a ansiedade ocasionadas por situações estressantes, como a hospitalização. Objetivo: Analisar os efeitos do uso da música sobre a ansiedade de crianças e adolescentes submetidos a tratamento quimioterápico para o câncer em unidades hospitalares. Método: Pesquisa de campo, descritiva, com abordagem qualitativa, realizada no Hospital Infantil Darcy Vargas, com participação de 17 pacientes. Resultados: ao desfrutarem da música como forma de terapia, crianças e adolescentes internados relataram, principalmente, o sentimento de alívio e conforto. a preferência por esse tipo de terapia, dentre a população estudada, foi entre os adolescentes, pois é uma faixa etária que utiliza esse recurso com mais frequência. Através da pesquisa, foi ainda mais evidente o poder e a influência que a música proporciona as crianças e adolescentes com câncer. a repercussão no alívio da ansiedade foi diretamente relacionada com os sentimentos e reações positivas produzidas pela música. Considerações Finais: Os dados mostraram que a música como terapia constitui-se de fato em um recurso viável, adequado e importante para o enfrentamento da hospitalização e pode ser mais utilizado quando a criança e adolescente encontram apoio nas ações institucionais que viabilizam e disponibilizam recursos humanos e materiais para este fim. a música, portanto, é uma ferramenta pouco utilizada nos serviços de saúde, mas capaz de humanizar, transformar e trazer alívio à ansiedade durante o momento de hospitalização da criança e adolescente com câncer.

Palavras-chave: Música; Criança; Adolescente; Câncer; Ansiedade; Enfermagem.

Menezes, Evelyn Torres de; Muniz, Camila Silva. A Música como Ferramenta Terapêutica no Cuidado a Crianças e Adolescentes Internados com Câncer. In: Anais do Congresso Internacional de Humanidades \& Humanização em Saúde [= Blucher Medical Proceedings, num.2, vol.1]. São Paulo: Editora Blucher, 2014. ISSN 2357-7282

DOI 10.5151/medpro-cihhs-10153 